DOI https://doi.org/10.30525/978-9934-26-038-4-56

\title{
ПОРІВНЯЛЬНИЙ АНАЛІЗ АКТИВНОСТІ ФЕРМЕНТІВ ЦТК ПРИ АЛОТРАНСПЛАНТАЦІЇ ЕМБРІОНАЛЬНОЇ СТЕГНОВОЇ М'ЯЗОВОЇ ТКАНИНИ У ЩУРІВ
}

\author{
Кобильник С. М. \\ асистент кафедри мікробіології, вірусології та імунології \\ Одеський національний медичний університет
}

Кагляк М. Д.

асистент кафедри мікробіології, вірусології та імунології

Одеський національний медичний університет

Ніколасва О. В.

кандидат біологічних наук,

асистент кафедри мікробіології, вірусології та імунології

Одеський національний медичний університет

Грузевський О. А.

кандидат медичних наук,

доцент кафедри мікробіології, вірусології та імунології

Одеський національний медичний університет

Дениско Т. В.

асистент кафедри мікробіології, вірусології та імунології

Одеський начіональний медичний університет

м. Одеса, Украӥна

Мета дослідження: провести порівняльний аналіз активності ферментів піруватдегідрогенази і $\alpha$ - кетоглутаратдегідрогенази при алотрансплантаціїембріональної стегнової м'язовоїтканини донора та реципієнта у щурів.

3'ясування біохімічних механізмів резистентності організму до критичних станів, являє собою важливу медико - біологічну проблему. До таких станів, в вчасності, відноситься трансплантація органів і тканин, яка $\epsilon$ актуальною проблемою в сучасній біології та медицині. Що стосується біохімічних перетворень при метаболізмі в самому трансплан- 
таті, які лежать в основі морфологічних і функціональних процесів, що протікають в м'язовій тканині донора вивчені недостатньо [1, с. 217].

Цикл трикарбонових кислот - це загальна для всіх клітин універсальна, високоспеціалізована біохімічна система, яка переводить хімічну енергію молекул в таку форму, в якій вона може використовуватися клітинами. Він $\epsilon$ центром, в якому сходяться практично всі метаболічні шляхи [2, с. 365]. Кребс також підтвердив, що виявлені раніше втканинах тварин органічні кислоти, стимулюють окислення пірувату. Крім того, він знайшов, що окислення пірувату м'язовою тканиною стимулюється багатьма органічними кислотами, в тому числі і $\alpha$ кетоглутаровою кислотою [3, с. 22]. В процесі загоєння рани спостерігають три фази: 1 - самоочищення рани; 2 - заповнення іiї грануляціями; 3 - рубцювання і епідермізація [4, с. 87].

Всі дослідження проводили на 122 білих лабораторних статевозрілих щурах (самцях та самицях) масою 180 - 320 г. Експерименти проводили згідно з Європейською конвенцією ( ETS №123 )про захист хребетних тварин, які використовуються в експериментальних цілях. Для отримання м'язової стегнової тканинивикористовували ембріони віком 3 - 3,5 тижні. Хірургічні втручання проводили в умовах дотримання норм загальних правил асептики. Ембріональну стегнову м'язову тканину підсаджували до аналогічної м'язової тканини реципієнта. Для порівняння результатів основного експерименту ми провели серію дослідів без підсадки (удавана операція), шляхом хірургічного розрізу і зшивання стегнової м'язи дорослого щура. Отримані результати активності досліджуваних ферментів порівнювали відносно контролю та удаваної операції, що дозволило нам визначити вплив саме алотрансплантації ембріональної стегнової м'язової тканини (донора) на тканину дорослого щура (реципієнта).

Для визначення активності ферментів піруватдегідрогенази і $\alpha-$ кетоглутаратдегідрогенази застосовували метод Габлера [5, с.3112- 3120] в модифікаціі Кісслінга і Лундквіста [6, с. 189-197]. За методом Стьюдента здійснювали статистичну обробку результатів [7, с. 48 - 50] .

Отримані результати активності піруватдегідрогенази в тканині реципієнта при алотрансплантації ембріональної стегнової м'язової тканини свідчать про те, що достовірних змін активності не виявленовідносно контролю. В тканині донора спостерігалось збільшення активності піруватдегідрогенази в усі терміни дослідження (таблиця 1). 
Таблиця 1

\section{Активність ферментів ЦТК при алотрансплантаціїембріональної} стегнової м'язової тканини у щурів

(нМоль ферриціаніду на г тканини)

\begin{tabular}{|c|c|c|c|c|c|c|c|c|}
\hline \multirow{2}{*}{ Тканина } & \multicolumn{3}{|c|}{ Стегнова м'язова тканина } & \multicolumn{3}{c|}{ Стегнова м'язова тканина } \\
реципінта & \begin{tabular}{c} 
Конт- \\
роль \\
\cline { 2 - 9 }
\end{tabular} & $\begin{array}{c}1 \\
\text { доба }\end{array}$ & $\begin{array}{c}3 \\
\text { доба }\end{array}$ & $\begin{array}{c}7 \\
\text { доба }\end{array}$ & $\begin{array}{c}\text { Кон- } \\
\text { троль }\end{array}$ & $\begin{array}{c}1 \\
\text { доба }\end{array}$ & $\begin{array}{c}3 \\
\text { доба }\end{array}$ & $\begin{array}{c}7 \\
\text { доба }\end{array}$ \\
\hline $\begin{array}{c}\text { Пермент } \\
\text { Піруватдегідро- } \\
\text { геназа }\end{array}$ & $50 \pm 3$ & $40 \pm 5$ & $60 \pm 7$ & $60 \pm 8$ & $90 \pm 2$ & $\begin{array}{c}50 \pm 1 \\
*\end{array}$ & $\begin{array}{c}80 \pm 1 \\
*\end{array}$ & $\begin{array}{c}80 \pm 1 \\
*\end{array}$ \\
\hline $\begin{array}{c}\alpha \text {-кетоглутарат- } \\
\text { дегідрогеназа }\end{array}$ & $20 \pm 1$ & $\begin{array}{c}50 \pm 2 \\
*\end{array}$ & $\begin{array}{c}60 \pm 8 \\
*\end{array}$ & $\begin{array}{c}80 \pm 5 \\
*\end{array}$ & $70 \pm 1$ & $\begin{array}{c}50 \pm 2 \\
*\end{array}$ & $\begin{array}{c}50 \pm 1 \\
*\end{array}$ & $\begin{array}{c}90 \pm 1 \\
*\end{array}$ \\
\hline
\end{tabular}

* $P \geq 0,05$ - достовірно відносно контролю

Алотрансплантація ембріональної стегнової м'язової тканини призвела до достовірного збільшення активності $\alpha$ - кетоглутаратдегідрогенази в усі терміни дослідження відносно контролю. В тканині донора активність досліджуваного ферменту зменшувалась на першу та третю добу дослідження, та к сьомій добі достовірно перевищувала контрольні значення.

В наступній серії дослідження ми визначали активність ферментів при удаваній операції (таблиця 2).

Таблиця 2

Активність ферментів ЦТК при удаваній операції (нМоль ферриціаніду на г тканини)

\begin{tabular}{|c|c|c|c|c|}
\hline \multirow{2}{*}{ Фермент } & \multicolumn{4}{|c|}{ Стегнова м'язова тканина } \\
\cline { 2 - 5 } & контроль & 1 доба & 3 доба & 7 доба \\
\hline Піруватдегідрогеназа & $50 \pm 1$ & $50 \pm 2$ & $54 \pm 7$ & $\begin{array}{c}28 \pm 3 \\
* * *\end{array}$ \\
\hline$\alpha$-кетоглутаратдегідрогеназа & $20 \pm 1$ & $53 \pm 1^{*}$ & $58 \pm 5^{*}$ & $\begin{array}{c}33 \pm 5 \\
* * *\end{array}$ \\
\hline
\end{tabular}

$* P \geq 0,05$ - достовірно відносно контролю

**P $\geq 0,05$ - достовірно між тканинами рещипієнта при алотрансплантації ембріональної тканини та удаваній операщії

Удавана операція на сьому добу дослідження призвела до зменшення активності досліджуваних ферментів. При порівнянні активності досліджуваних ферментів в тканині реципієнта між алотрансплантацією ембріональної тканини та удаваною операцією, було визначено достовірне зменшення активності ферментів при удаваній операції.

Таким чином, встановленийпозитивний вплив алотрансплантації стегнової м'язової тканини на активність піруватдегідрогенази та $\alpha$ кетоглутаратдегідрогенази на сьому добу дослідження. 


\title{
Література:
}

1. Касавина Б.С., Торбенко В.П. Жизнь костной ткани. Москва, наука. 2004. С. 217.

2. Нельсон Д., Кокс М. Основи биохимии Ленинджера. Москва. 2015. T. 2. С. $181-187$.

3. Трубачёв С.Д., Заруба Н.С., Чащина Е.Е. Биологическое окисление. Екатеринбург, 2002. С. 22.

4. Мазур О.С., Активність ферментів енергетичного обміну ембріональніх трансплантатів: Автореф. дис. , К., 2008. С. 87.

5. Gabler C. Studies on the physiological function of thiamine / J. Biol. Chem. - 1961. - № 12. - P. 3112-3120.

6. Kiessling R.H., Lundquist I.I. Thiamin diphosphate in growind fissues. III. Pyruvate oxidation in liver mitochondria from young and from thiamine diphosphate deficient adult rats. Experim. Cell Kes. - 1962. - № 26. P. $189-197$.

7. Камкіна Л.В., Надточій А.А., Гришин О.М., Стогній Ю.Д. Навчальний посібник. Дніпропетровськ: НМетАУ. 2013. С. 48-50.

DOI https://doi.org/10.30525/978-9934-26-038-4-57

\section{ОЦІНКА ВПЛИВУ ІНФОРМАЦЙНО-КОМУНІКАЦЙНИХ ТЕХНОЛОГІЙ НА ПСИХОФУНКЦІОНАЛЬНИЙ СТАН ОРГАНІЗМУ ПІДЛІТКІВ ЗА СУБ'СКТИВНИМИ ПОКАЗНИКАМИ}

\author{
Коцур Н. I. \\ доктор історичних наук, професор, \\ завідувач кафедрою медико-біологічних дисииплін і валеології \\ Університет Григорія Сковороди в Переяславі
}

\section{Товкун Л. П.}

кандидат історичних наук,

дочент кафедри медико-біологічних дисииплін і валеології, завідувачка навчально-методичної лабораторї діагностики здоров 'я $i$ профілактики захворювань Університет Григорія Сковороди в Переяславі м. Переяслав, Київська область, Украӥна

Одним із важливих напрямків розвитку інформатизації освіти є нові комп'ютерні технології. Інтенсифікація освітнього процесу, інтерактивність, зворотний зв'язок - помітні переваги цих технологій, котрі 